\title{
Técnica e educação em tempos de indigência
}

Wanderley Jose Ferreira

Universidade Federal de Goiás

\section{Resumo}

Procura-se refletir sobre as possíveis articulações entre técnica e educação no âmbito do pensamento heideggeriano. Tomando como ponto de partida os possíveis limites da analítica existencial de Ser e Tempo em questionar o fenômeno da técnica moderna, explicita-se como a questão da técnica articulase com a questão da formação humana no Discurso de Reitorado (A autoafirmaçãoda universidade alemã) (1933). Caracterização da essência da técnica moderna na fase terminal da metafísica explicitando em que sentido em tal época vivemos um estado de indigência e penúria, impotentes para pensar. Em um terceiro momento procura-se pensar as alternativas que se abririam à formação humana no contexto de uma época considerada pós-humanista.

Palavras-chaves: Técnica; Educação; Humanismo.

\section{Résumé}

Cherche à réfléchir sur les liens possibles entre la technique et l'éducation dans le contexte de la pensée de Heidegger. Prenant comme point de départ les limites possibles de l'analyse existentielle de l'Etre et Temps de faire face au phénomène de la technique moderne, est expliquée comme une question de technique est liée à la question de la formation humaine dans le discours controversé Discours du Rectorat. Caractérisation de l'essence de la technique moderne dans la phase terminale de la métaphysique expliquant dans quel sens un tel moment vivons dans un état de dénuement et la misère impuissante à penser. Dans un troisième moment se reflète les solutions qui s'ouvre à la formation humaine dans le contexte d'une époque considérés comme posthumaniste.

Mots-clés: Technique; Éducation; Humanisme. 


\section{Introdução}

o tentar refletir sobre as possíveis articulações entre técnica e
educação no âmbito do pensamento heideggeriano, estamos
conscientes de que vamos nos deparar com questões que, além de não terem sido explicitamente abordadas por Heidegger, serão tratadas aqui no horizonte teórico de algumas obras muito citadas e referenciadas, mas muito mal compreendidas em suas motivações, objetivos e consequências.

Em um primeiro momento procura-se demarcar os possíveis limites da analítica existencial de Ser e Tempo face ao fenômeno da técnica moderna, para logo a seguir explicitar como a questão da técnica articula-se com a questão da formação humana no polêmico Discurso de Reitorado (A auto-afirmação da universidade alemã) (1933). Na analítica existencial realizada em Ser e Tempo (1927) a questão da técnica ainda não é explicitamente colocada. No mundo constituído pelo Dasein, o ocupar-se enquanto um deixar-surgir o ente num mundo já previamente descoberto, em nada se assemelharia a intervenção provocadora promovida pela técnica e seu poder desafiador.

Na medida em que na Analítica existencial o mundo torna-se um fenômeno que emerge na conexão da totalidade dos utensílios, que se apoiam num último para-quê fundado no próprio Dasein, a técnica não passaria de um dos modos de ser possíveis do Dasein manipular e velar os entes intramundanos que lhe vêm ao encontro. Sendo assim, a técnica ainda não era, e nem poderia ser, questionada por Heidegger como um princípio epocal $^{l}$ que na história do Ser consumaria a metafísica ocidental no mundo objetivado do cálculo. $\mathrm{O}$ fato é que Heidegger viu-se obrigado a ultrapassar

\footnotetext{
${ }^{1}$ Princípio Epocal: Noções fundamentais da linguagem metafísica que determinam o modo de dizer e pensar o Ser em determinada época da Metafísica(Eidós, Energéia, Deus, Cogito, Sujeito Transcendental, Sujeito Absoluto, Vida, vontade de potência, e a Técnica). Ao destruir a história da Metafísica ocidental, Heidegger procura desvelar o que permaneceu não-dito e impensado nesses princípios epocais.
}

Filosofia e Educação - ISSN 1984-9605

Volume 6, Número 3 - Outubro de 2014 
os limites da analítica existencial de Ser e Tempo para questionar a essência da técnica moderna e apontar uma alternativa ao pensamento calculador.

Foi a partir do contato com Jünger, que Heidegger procurou refletir um fenômeno que hoje atinge dimensões planetárias - a mobilização total do mundo pela técnica. O que colocou ao filósofo a necessidade de uma retomada da história da metafísica enquanto história do esquecimento do Ser, com o objetivo de compreender a possibilidade de ultrapassar o império da técnica moderna. Mas como tal questão articula-se com a educação já no polêmico Discurso de reitorado (1933)?

Retomaremos algumas passagens do Discurso de Reitorado (1933), nas quais o filósofo passa a admitir que no começo da filosofia grega haveria um poder espiritual mais elevado capaz de se opor à vontade de potência presente na fúria desenfreada da técnica moderna. Mas já que o novo começo de um pensamento meditante não poderia mais se inspirar no começo grego da filosofia, resta ao filósofo determinar em que medida se constituiu uma certa concepção de Ser do ente e da verdade considerando algumas distorções nos significados de termos fundamentais da metafísica (de alétheia para a adaequatio; da Energéia à actualitas, do hypokeimenon ao sub-jectum, etc.) que culminaram no reino planetário da técnica.

Em um segundo momento procura-se caracterizar a essência da técnica moderna na fase terminal da metafísica tomando como referência básica o texto da conferência pronunciada em 1953 sob o título A questão da técnica. Tentaremos esclarecer em que sentido Heidegger afirma que $a$ essência não técnica da técnica não pode ser tematizada nos limites de uma concepção antropológico-instrumental.

Contudo, como veremos, a herança longínqua da téchne grega é a técnica moderna, que é, também um desabrigar, mas que não se desdobra num levar à frente, no trazer à presença, no sentido da poiesis. Veremos que, para Heidegger, o desabrigar imperante na técnica moderna é um desafiar (Herausfordern) que estabelece para a natureza a exigência de fornecer energia suscetível de ser extraída e armazenada enquanto tal. Tentaremos

Filosofia e Educação - ISSN 1984-9605

Volume 6, Número 3 - Outubro de 2014 
explicitar em que sentido esse modo de desabrigar da técnica moderna é um destino (Geschick) que nunca é, porém, a fatalidade de uma coação, pois o homem se torna livre na medida em que pertence ao âmbito desse destino. Tentaremos explicar aqui em que sentido o destino do desabrigar traz em si um perigo, que não é em si qualquer perigo, mas é o perigo, na medida em que se apresenta como segurança, progresso e bem-estar em meio à indigência e à penúria de uma época que já não pensa.

Em um terceiro momento vamos abordar as alternativas e limites para a formação humana no contexto de uma época considerada pós-humanista. Dentre nossas referências básicas aqui podemos destacar: um pequeno livro intitulado Regras para o parque humano, do pensador Peter Sloterdijk, e a carta resposta de Heidegger a Jean Beaufret Sobre o humanismo, no qual o autor faz uma crítica aos humanismos (Cristianismo, Marxismo, Existencialismo) por não pensarem em sua radicalidade a essência do ser humano enquanto Ser-aí (Dasein). Como pensar a questão da formação humana numa época pós-humanista? Mais que uma resposta, vamos tentar compreender os desdobramentos de tal questão e os desafios que se colocam a nós educadores de um tempo indigente.

\section{A questão da técnica e sua articulação com a educação no Discurso de Reitorado}

\section{A impossibilidade de se pensar a técnica no âmbito da analítica existencial de Ser e Tempo}

Vamos retomar aqui alguns aspectos da analítica existencial de Ser e Tempo (1927) com o objetivo de ressaltar seus limites e possibilidades em relação à questão da técnica moderna. Isso não significa, contudo, que o projeto de Ser e Tempo de re-colocar a questão do sentido e da verdade do Ser seja abandonado nas obras posteriores de Heidegger, quando a questão da técnica assumirá uma importância crescente na obra do filósofo enquanto fase terminal da metafísica. O próprio Heidegger, em suas análises

Filosofia e Educação - ISSN 1984-9605

Volume 6, Número 3 - Outubro de 2014 
retrospectivas de Ser e Tempo, admite que essa obra já está a caminho da superação da metafísica, na medida em que retoma a questão do Ser em uma nova base - a existência humana que compreende o Ser e em um novo horizonte - o Tempo.

A analítica existencial, ao destruir a noção de natureza em Descartes, desvelaria uma outra natureza que se fundamentaria na mundanidade do mundo. Entretanto, o desvelamento dessa dimensão originária de nossa relação com o mundo não ofereceria, e nem poderia oferecer, nenhuma perspectiva de superação do reino planetário da técnica. Em Ser e Tempo, a oposição entre natureza e técnica perde sua força na medida em que a instrumentalidade dos instrumentos não nos conduz a um mundo oposto à natureza. Portanto, no âmbito da fenomenologia do ser-àmão, desvela-se uma espécie de natureza que se distinguiria da natureza desafiada pela técnica, ou seja, como sendo o domínio de presentidades, de substâncias e forças que estão simplesmente aí (Loparic, 1996, p. 111). Apesar disso, poderíamos até supor que em Ser e Tempo teríamos a possibilidade de liberar os entes da objetivação do pensamento calculante e da representação, ao revelar uma compreensão pré-filosófica e a-histórica do instrumento numa dimensão pré-reflexiva em que o Dasein está originariamente comprometido com o mundo.

O que nos parece claro é que na analítica existencial de Ser e Tempo o mundo emerge como parte da estrutura unificante do ser-nomundo, constituindo assim um complexo de relações que se articulam em uma totalidade originária - a Bedeutsamkeit (Significância). Essa significância compreende a totalidade das relações de significação que o Dasein mantém com o mundo e os outros. Ela seria o que forma a estrutura do mundo. O Dasein desde sempre estaria, assim, familiarizado com a significabilidade, ou seja, com a totalidade de relações e remissões que conferem sentido ao para-quê dos instrumentos e que remetem, em última instância, à estrutura ontológica do próprio Dasein como ser-no-mundo, não 
mantendo uma relação de desafio com uma suposta natureza reduzida a estoque de reserva (Bestand) (Heidegger, 1988, p. 71 e 87).

Entretanto, se é certo que em Ser e Tempo não há lugar para o desafio da técnica moderna que intima e reduz a natureza a um estoque de reservas, também ali não existe mais uma abertura ao ente tal como ele se manifesta a partir de si mesmo, ou seja, tal como os Gregos o experienciavam. É pensando na experiência do Ser expressa no dizer e no pensar dos pensadores e poetas gregos anteriores à viragem platônica, que Heidegger considera o pensamento fundamental como aquele cujos pensamentos não apenas calculam, mas são determinados pelo outro do ente, ou seja, o próprio Ser. Em vez de calcular com o ente e sobre o ente, o pensamento originário dos pensadores gregos (pré-socráticos) se dissipa no Ser pela verdade do Ser, respondendo ao seu apelo. Não é por acaso, portanto, que Heidegger no início dos anos trinta em seu Discurso de Reitorado $(1933)^{2}$, já sob influência de Ernst Jünger, expressa a crença de que uma volta aos gregos poderia nos oferecer uma saída ou a possibilidade de superação do domínio planetário da técnica.

\section{Discurso de Reitorado: o retorno malogrado aos gregos}

Heidegger reconhece que a questão da técnica surge com maior força em seu pensamento sob a inspiração de duas obras de Ernst Jünger: Mobilização Total (Totale Mobilmachung) (1930) e O trabalhador (Der Arbeiter) (1932). Entretanto, em Que é Metafisica?, aula inaugural proferida em 1929 na Universidade de Freiburg, o filósofo já se propunha a desenvolver o horizonte metafísico em que o cientista antecipa a visão da totalidade e clarifica as condições de sua própria existência de pesquisador. A partir da transcendência exercida pelo Dasein em seus modos de ser concretos, Heidegger procura destacar as possibilidades e os limites da

\footnotetext{
${ }^{2}$ A paginação das citações no corpo do texto obedece à edição portuguesa - Cf. Heidegger, M. A auto-afirmação da Universidade alemã. Trad. Fausto Castilho. Op. Cit. 1997. (Edição Bilíngue). Cf. Heidegger, M. Die Selbstbehauptung der Deutschen Universität. Op. Cit. GA 19.
}

Filosofia e Educação - ISSN 1984-9605

Volume 6, Número 3 - Outubro de 2014 
pesquisa científica, do cálculo e da técnica, apontando para o advento de um novo pensar que conduziria o homem novamente à sua terra natal. $\mathrm{O}$ texto da preleção foi publicado no mesmo ano com intensa repercussão e provocando muitos mal entendidos. Para os críticos, a aula de Heidegger parecia reforçar certas suspeitas já despertadas em Ser e Tempo. O filósofo seria um promotor do niilismo, da filosofia do sentimento de angústia e da covardia, do irracionalismo.

O fato é que, em sua preleção e diante de colegas e alunos perplexos, Heidegger elabora sua crítica à ciência e aponta para a existência de um pensar mais originário que o pensar calculador. Os domínios das ciências estão cada vez mais distantes. Há uma multiplicidade de métodos e procedimentos científicos para tratar objetos também diversos. Esta dispersão de disciplinas é hoje ainda apenas mantida numa unidade pela organização técnica de universidades e faculdades e conserva um significado pela fixação das finalidades práticas das especialidades. (Heidegger, 1979, p. 35).

Portanto, já em 1929 o diagnóstico de Heidegger é claro: o enraizamento das ciências em seu fundamento essencial desapareceu. Em todas as ciências nós nos relacionamos com o próprio ente. A referência ao mundo que impera nas ciências faz com que elas procurem o ente para, conforme seu conteúdo essencial e seu modo de ser, transformá-lo em objeto de investigação.

Podemos considerar, portanto, que o encontro com Jünger no início da década de 30 de certa forma veio contribuir para que Heidegger aprofundasse sua crítica ao domínio do pensamento calculador na era da técnica planetária

Em $O$ trabalhador, por exemplo, o real torna-se manifesto como trabalho, a técnica seria a vontade de potência (Nietzsche) corporificada na Figura do trabalhador. A técnica, por sua vez, gera uma mobilização total mediante a qual toda vida é transformada em energia que alimenta e responde ao seu poder desafiador. Essa mobilização total tem como 
resultado um processo de trabalho que tem como protagonista a figura titânica do trabalhador. A técnica, assim como a vontade de potência, apesar de submeter incondicionalmente $\mathrm{o}$ homem e a totalidade do ente à planificação total, não possuiria meta alguma senão o aumento de seu domínio sobre a totalidade do ente.

$\mathrm{Na}$ tentativa de superar esse domínio planetário da técnica e o desarraigo do homem, Heidegger fala, em seu Discurso de Reitorado (1933), de um lugar onde ainda vigorava o pensamento do Ser. Um lugar que não era mais a existência finita do Dasein, mas que teria se manifestado no começo $\left(\right.$ Anfang) ${ }^{3}$ da filosofia grega (cf. Heidegger, 1997). Contudo, o filósofo não permaneceria por muito tempo nesse caminho de retorno aos gregos. Já no final da década de 30, ao fazer um balanço de seu curto período de reitorado, Heidegger reconhecerá que o seu discurso de posse teria falhado ao não tematizar a essência não técnica da técnica moderna e ao não reconhecer que a vontade de potência, que caracteriza a técnica e a ciência moderna, já estava presente na origem grega da filosofia.

No "tudo é água" de Tales já estaria presente, como em todo conhecimento racional e objetivável, a fúria da técnica que intima a natureza a apresentar-se em sua calculabilidade, ainda que Tales, como a maioria dos pensadores originários anteriores a Sócrates, experienciasse em seu dizer e pensar a natureza como physis, ou seja, aquilo que por si brota, emerge, abre-se e se manifesta enquanto princípio originário, regulador e fim de todas as coisas. A physis é o próprio Ser que torna possível o demorar, o estar estendido diante de... A aurora, o nascimento das plantas, dos animais e dos homens, a montanha, a pedra, o pensar e o agir de homens e deuses, etc. Tudo é physis. Para Heidegger, por haver conservado apenas o sentido estático do Ser, ou seja, o Ser como Ousia (Substância), como a pura efetividade, o que está aí diante de mim, a metafísica ocidental tornou-se o

\footnotetext{
${ }^{3}$ Heidegger utiliza de forma diferente dois termos que equivocadamente são traduzidos como sinônimos: o Início (Beginn) e o Começo (Anfang). O início indica o mero ponto de partida de algo. O começo descreve a gênese mesmo desse ponto de partida e a presença do princípio de constituição dessa gênese. O começo estende-se assim para além do início, pois a gênese de algo continua determinante ao longo do caminho de sua realização.
}

Filosofia e Educação - ISSN 1984-9605

Volume 6, Número 3 - Outubro de 2014 
lugar onde acontece o esquecimento do Ser. Cabe rememorar, portanto, o sentido originário de Ser como physis, a pura possibilidade, o abismo sem fundo de onde o ente essencializa seu próprio Ser (cf. Heidegger, 1987a).

O fato é que houve uma época, no início dos anos 30 do século passado, em que Heidegger parece ter acreditado que poderia "ultrapassar" ou pelo menos deter a fúria desenfreada da Técnica mediante um retorno à origem grega da filosofia e da ciência e, logicamente, apostando que a revolução nacional-socialista fosse levar a Alemanha para uma terceira via, livrando-a tanto do comunismo quanto do capitalismo-americanismo, ambos dominados pela fúria da técnica expressa na planificação total.

No Discurso de Reitorado, o pensador deixa claro que o lugar de origem do pensamento do Ser não seria mais instaurado no âmbito da existência finita como parecia indicar a analítica existencial de Ser e Tempo, mas teria sua origem na grandeza originária da filosofia grega, quando pela primeira vez um povo teve a coragem de colocar a totalidade do ente em questão (Heidegger, 1997, p. 4).

Heidegger começa seu Discurso de Reitorado afirmando que a ciência deve estar a serviço da Universidade na educação e na elevação de seus guias (Führer), enquanto guardiões do destino do povo. Ciência e destino do povo devem, nessa vontade de ciência, chegar ao mesmo tempo à força. Isso exigiria que professores e alunos exponham a ciência e sua necessidade mais íntima e suportem o destino do povo em sua necessidade mais extrema (Heidegger, 1997, p. 3). Contudo, alerta o filósofo, experienciar a essência da ciência em sua necessidade mais íntima não significa submeter-se aos modismos e ao falatório sobre um novo conceito ou paradigma científico.

Para apreendermos a essência da ciência, temos de primeiramente encarar uma questão decisiva:

para nós a ciência deve continuar a ser ou devemos deixá-la encaminhar-se para um fim rápido? Nunca é algo incondicionalmente

Filosofia e Educação - ISSN 1984-9605

Volume 6, Número 3 - Outubro de 2014 
necessário que a ciência como tal deva ser. Supondo-se, porém, que a ciência deva ser e deva ser para nós e por nós, sob que condição pode ela verdadeiramente consistir? (Heidegger, 1997, p. 3)

Ora, tais condições, na perspectiva de Heidegger, teriam sido dadas no começo de nosso Dasein enquanto povo Ocidental, ou seja, no nascimento da filosofia grega, quando pela primeira vez, a partir do caráter de um povo e por força de sua língua, o homem ergue-se diante do ente em sua totalidade e o interroga. "Toda ciência é filosofia, quer saiba e quer queira ou não. Toda ciência permanece cativa daquele começo da Filosofia e dele retira a força de sua essência, supondo-se que, como tal, ela ainda permanece à altura desse começo." (Cf. Heidegger, 1997, p. 4) Isso certamente deveria repercutir no modo como se ensina e se aprende em nossas universidades, que privilegiam o conhecimento em detrimento do pensar e a transmissão passiva de um saber já pronto, que apenas legitima a formação, ou melhor, a profissionalização de servidores desse deus onipotente chamado mercado.

Apesar de o progresso ter modificado a ciência e a paisagem da terra, isto não faz do começo grego da filosofia (e da ciência) algo ultrapassado ou mesmo aniquilado em um passado distante. $\mathrm{O}$ começo ainda é. Ele está diante de nós. Ele já passou antecipadamente por sobre tudo que viria e projetou-se para além de nós mesmos. O começo permanece em nosso futuro. Como um apelo distante, nos insta a que resgatemos sua grandeza. O fato é que, se não nos tornarmos dignos da grandeza desse começo grego da filosofia e da ciência, então a ciência se tornará para nós um mero acaso no qual caímos, ou o calmo prazer de fazer, sem perigo, simplesmente avançar os conhecimentos (Heidegger, 1997, p. 7).

Em sua proposta visando a enquadrar a universidade na "nova ordem" proposta pela revolução nacional-socialista, Heidegger fala de uma obrigação da comunidade estudantil, que a vincularia à missão espiritual do povo alemão - o serviço do saber. Um saber autêntico que jamais estaria a 
serviço das profissões e do mercado. Um saber cuja essência seria o combate.

Segundo Heidegger, todas as vontades e pensamentos, todas as forças do coração e todas as aptidões da carne devem ser desenvolvidas pelo combate, se reorientar no combate e se conservar enquanto combate (Heidegger, 1997, p. 16). Paradoxalmente, esse saber fundamental que rompe os limites artificiais entre as diversas especialidades e que surge quando um povo (grego) ousa colocar em questão a totalidade do ente, é aquele que, ao mesmo tempo que poderá nos salvar de uma plena planificação do real e do agir, é também a fonte a partir da qual se essencializa o pensamento calculador moderno e seu projeto matemático de natureza. Entretanto, como já observamos, já no final dos anos 30 o filósofo reconhecerá o equívoco de seu polêmico Discurso de reitorado, que teria negligenciado aspectos importantes da modernidade e da ciência ao não perceber que a vontade de potência, que impera no reino da técnica moderna, é a mesma que sustém a vontade de saber no começo da filosofia grega.

É importante observar que em seu Discurso de Reitorado (1933) Heidegger expressa esperanças de que a revolução nacional-socialista pudesse promover a integração do homem do presente com a técnica planetária. Entretanto, já em 1935/6 razões filosóficas teriam conduzido Heidegger a uma crítica da técnica moderna e do nacional-socialismo. O filósofo teria percebido que tanto a racionalidade técnica quanto o nazismo não passariam de sintomas de uma mesma subjetividade tirânica e ávida em dominar e planificar toda práxis humana. Uma subjetividade que já estava presente no começo da filosofia grega.

Heidegger passará a falar de um outro começo do pensamento do ser, mais inicial que o grego e capaz de nos libertar da herança do primeiro começo: o domínio incondicional da totalidade do ente pelo pensamento calculador no reino da técnica planetária (cf. Loparic, 1996, p. 121). Podemos considerar então que no início da década de 30 , o filósofo 
ainda não teria compreendido que a história da metafísica, desde sua origem entre os gregos, representava um esquecimento/velamento crescente do Ser, e que a técnica seria sua fase terminal - a última época nessa errância do Ser. Heidegger assume então, como tarefa, a rememoração das mutações fundamentais no modo de dizer e pensar o Ser e sua verdade ao longo da tradição Ocidental que se consuma hoje na técnica planetária e em sua fúria em querer planejar e organizar a práxis humana.

Mas como explicitar o caráter da técnica moderna e seu domínio? Como compreender esses tempos de indigência e penúria em meio aos sucessos ruidosos da técnica? E que repercussões isso teria para a formação humana em um mundo uniformizado pelo cálculo?

\section{Era da técnica e hegemonia do pensamento calculador: indigência e penúria}

Ao abordar a questão da técnica, Heidegger não se interessa em realizar uma abordagem antropológico-instrumental de tal fenômeno e de seus efeitos práticos. Para o filósofo, a tarefa que se imporia no momento seria tentar refletir em que sentido a Era da Técnica consuma toda história de errância da Metafísica Ocidental e qual a natureza do pensamento apto a colocar em questão a essência, até então, impensada da Técnica.

A expressão "questão da técnica" deve ser ouvida e compreendida da mesma forma que devemos ouvir e pensar a Seinsfrage, ou seja, a questão do Ser no duplo sentido do genitivo objetivo e subjetivo. A questão da técnica não é apenas uma questão que tem a técnica como objeto, mas é a própria técnica, enquanto manifestação epocal do próprio Ser, que interroga a si mesma nessa questão. Daí a necessidade de rememorar a experiência do ser e de sua verdade que se desdobra ao longo da história da metafísica e que se consuma hoje na dominação incondicional da técnica moderna sobre a totalidade do ente. Mas haveria sentido, perguntam alguns críticos, em falar em essência não técnica e impensada da técnica?

Filosofia e Educação - ISSN 1984-9605

Volume 6, Número 3 - Outubro de 2014 
Para responder tal questão, reportemos ao texto da famosa conferência pronunciada por Heidegger em 1953 sob o título A pergunta pela Técnica (Die Frage nach der Technik) e na qual o filósofo procura compreender o fenômeno da técnica para além dos limites de uma concepção antropológico-instrumental, estabelecendo ao mesmo tempo um contraponto entre o caráter da técnica moderna e a téchne grega.

Heidegger coloca em questão a técnica perguntando inicialmente pelo ser do instrumento. Ora, onde fins são perseguidos e meios são empregados, onde domina o instrumental, observa o filósofo, ali impera a causalidade (Ursächlichkeit). Portanto, perguntar pelo ser do instrumento, leva-nos a questionar o que seja a causalidade (cf. Heidegger, 1958a, p. 45). O termo grego aıtıov (causa) não significa efetuar, produzir um efeito, mas sim o estar comprometido, o ser responsável, ser culpável de algo vir à presença e desvelar-se a partir de um estado de velamento anterior. Os quatro modos de ocasionar deixam, pois, algo vir à pre-sença (An-wesen), conspiram para o aparecimento de algo que se encontrava oculto. A poiesis é esse pro-duzir (Her-vor-bringen) que ao não se limitar ao fazer artístico nem ao fazer técnico-manual, remeteria à própria physis. A essência da téchne estaria nesse descobrir, trazer à presença, que manteria uma relação essencial com o fenômeno da verdade enquanto des-velamento (alétheia) do ente em seu ser. (Cf. Heidegger, 1958a, p. 46)

A herança longínqua da téchne grega é a técnica moderna, que também implica um desabrigar, mas que não é um trazer à presença, no sentido da poiesis. O desabrigar que impera na técnica moderna tem o caráter de um desafio, uma intimação que reduz a natureza à condição de "autômato", de um estoque de reserva (Bestand). Entretanto, o inquietante é que esse descobrimento-desvelamento nunca é algo feito pelo homem. O homem é ele também provocado e inquirido pela essência da técnica - o Ge-stell (Armação). Isso porque o modo de desabrigar, tornar presente, da técnica moderna é um destino (Geschick) enquanto consumação da metafísica Ocidental e o homem só se torna livre na medida em que 
pertence ao âmbito desse destino. Um destino que traz em si um perigo, que não é em si qualquer perigo, mas é o perigo (cf. (Heidegger, 1958a).

\section{O processo de dessacralização do mundo}

O processo de dessacralização do mundo acontece ao mesmo tempo em que a Filosofia encontra seu fim como metafísica no âmbito da objetificação total de todas as dimensões da realidade (cf. Heidegger, 1958a, p. 82). Já não há mais terra, coisas ou homens, apenas o mundo estéril, asséptico e uniforme do calculo habitado por sujeitos e objetos. E na medida em que o homem é colocado como besta do trabalho, o niilismo e a devastação da terra encontram sua completude no mundo planificado pela técnica planetária. A técnica torna-se, assim, a organização da penúria no âmbito de uma fabricação em massa, que se transforma na única forma possível com a qual a vontade de vontade se mantém em ação e pode assim ser ela mesma o sujeito de todas as coisas em um mundo no qual tudo é substituível (cf. Heidegger, 1958a, p. 111-112).

No mundo uniforme do cálculo, as coisas padecem de uma ausência de diferença alimentada por ações regidas pelo princípio de produtividade. Essa ênfase na eficácia e produtividade obstrui as dimensões onde se poderia desenvolver uma relação mais originária com a terra, o mundo, as coisas, a linguagem. $\mathrm{O}$ inquietante é que o homem perdeu sua relação com a terra e as coisas enquanto tais, não devido a um acidental desenraizamento, é o projeto tecnológico que exclui a existência mesma de qualquer coisa que não seja disponível ao poder desafiador da técnica (Heidegger, 1958b, p. 113).

$\mathrm{Na}$ época do domínio planetário da técnica os pensadores devem suportar o destino de uma dupla distância, ou melhor, de uma dupla indigência - os deuses fugiram e não oferecem mais a segurança de sua proximidade e o verdadeiro ser das coisas retém-se em si, ou se retrai diante de qualquer tentativa de apreendê-lo pelo pensamento. O pensamento do Ser não vingou ainda o suficiente para poder desvelar o divino. Isso faz com que

Filosofia e Educação - ISSN 1984-9605

Volume 6, Número 3 - Outubro de 2014 
um dos fenômenos determinantes de nossa época seja a fuga dos deuses, ou seja, os homens e as coisas já não se reúnem mais na dimensão do Sagrado. Mas como o Sagrado poderá habitar novamente a terra, na ausência de um pensamento e de uma poesia capazes de o celebrar? O sagrado aqui significa aquilo que permanece salvo, ou seja, aquilo que permanece intacto, inacessível a toda manipulação, a toda instalação do dispositivo técnico. Entretanto, o reino planetário da técnica não permite mais ser salva nenhuma região da terra.

O que agrava e aprofunda nossa indigência é que não somente perdemos o caminho para o Sagrado, mas perdemos os caminhos que conduziam a esse caminho. Portanto, a aparente ausência de carência e de penúria de nossa época deve ser encarada como a máxima indigência, onde o que salva não está presente e não é sequer desejado no âmbito da mobilização total gerada pela técnica. Contudo, o que mais nos ameaça, não é a cultura técnico-científica, mas a ainda não pensada essência da técnica que já ameaçava nossos antepassados - é lá que se aloja o perigo, mas também o que salva.

\section{O perigo e o que salva}

Esse mesmo homem que se arroga ser o senhor e mestre da natureza e dominador da Terra desconhece tanto a essência da técnica quanto o perigo (Gefahr) que ela abriga. O perigo aqui não ameaça apenas o homem empírico, mas sua essência. Nesse sentido, a ameaça de uma instalação indefinida e total da técnica por toda terra representa para Heidegger uma perspectiva muito mais sinistra, uma ameaça de morte maior que toda ameaça de destruição física da humanidade por uma guerra nuclear. E a possibilidade de ultrapassamento da técnica dependeria de uma mudança de atitude em relação a ela e um novo olhar lançado em sua essência, vislumbrando o perigo que aí se aloja. Entretanto, esse perigo não deveria conduzir a uma condenação moral da mesma ou a sua pura e simples negação como algo demoníaco.

Filosofia e Educação - ISSN 1984-9605

Volume 6, Número 3 - Outubro de 2014 
O perigo não é verdadeiramente, senão quando o homem o olha, senão quando o pensamento saiba reconhecer, além dos aparentes progressos ou aperfeiçoamentos da realidade, uma ameaça à própria essência humana. Nós olhamos para o perigo, e nesse olhar vislumbramos ao mesmo tempo aquilo que salva. É o próprio poeta Hölderlin quem diz: onde o perigo aparece como perigo, é também já nascido aquilo que salva (cf. Heidegger, 1987b, p. 36). Não devemos esperar que onde exista o perigo também possamos imediatamente encontrar aquilo que salva. O perigo é ele mesmo isto que salva, se ele é visto como perigo. O que se torna difícil já que esse perigo aparece hoje com os sinais do progresso e do bem-estar.

O fato é que toda salvação que não provenha mesmo do perigo não livrará o homem da ameaça que lhe advém como destino. Enquanto o homem não aprender a olhar a essência da técnica e ver que ali se aloja não apenas o perigo, mas também o que salva, ele continuará sendo a "besta do trabalho" que, abandonada à vertigem de suas fabricações, dilacera a si mesma, caindo nas mais extremas indigência e penúria. Mas como falar de indigência em uma época em que os sinais do progresso são visíveis? Para Heidegger a indigência de nossa época estaria no fato de não pensarmos mais - pior, em não sentirmos sequer a necessidade de pensar.

\section{Indigência e penúria em meio à abundância}

Para Heidegger, a penúria/indigência de nossa época estaria no fato de ela estar sob o domínio do pensamento calculador. Vivemos em uma época que não pensa, apenas planifica e calcula conforme uma vontade de vontade, que, à semelhança da vontade de potência em Nietzsche, tem como único objetivo seu próprio engrandecimento. Entretanto, é no âmbito mesmo dessa indigência e penúria que surge a possibilidade do advento de uma nova forma de pensar e dizer mais originária. Um pensar e um dizer que poderão nos ajudar a superar essa sensação de estranhamento diante de um mundo cada vez mais uniformizado pelo domínio planetário da técnica, mediante o

Filosofia e Educação - ISSN 1984-9605

Volume 6, Número 3 - Outubro de 2014 
qual o esquecimento do ser atinge sua plenitude no mundo objetivado da planificação total.

$\mathrm{Na}$ conferência intitulada $O$ fim da filosofia e a tarefa do pensamento (Das Ende der Philosophie und die Aufgabe des Denkens) (1966), Heidegger coloca a nós, homens desse tempo indigente, duas questões cruciais: Em que medida nessa época de indigência e penúria, entrou a filosofia em seu estágio terminal? E qual a tarefa que ainda permaneceria reservada ao pensamento nesse fim da Filosofia? Ora, responder tais perguntas implica em colocar em questão a nós mesmos e nosso próprio tempo - o tempo da maior penúria/indigência. Entretanto, como já ressaltamos, é justamente em meio a essa extrema indigência que se abriria a possibilidade de uma nova tarefa ao pensamento - pensar a essência impensada da técnica e a clareira (Lichtung) na qual acontece a copertença Ser e homem.

Se o saber filosófico é de natureza diferente do conhecimento científico, verificado e confirmado a todo momento por sua eficácia, então como seria possível à filosofia ter chegado ao seu fimm mediante sua diluição nas ciências tecnizadas? O fato é que no reino planetário da técnica, a filosofia como Metafísica teria atingido suas "possibilidades supremas" dissolvendo-se no surto crescente das ciências que esvaziaram a problemática filosófica (Heidegger, 1987c, p. 71). Em tempos de penúria, a Filosofia transforma-se em ciência empírica do homem e de tudo que pode tornar-se objeto disponível para sua técnica, pela qual ela se instala no mundo. O fim da Filosofia seria assim o lugar onde o todo da história da metafísica atinge sua extrema possibilidade. Para Heidegger, esse todo da História da Filosofia é determinado pelo pensamento de Platão, ainda que em diferentes figuras. "A metafísica é platonismo. Nietzsche caracterizou sua filosofia como platonismo invertido. Com a inversão da metafísica, que já é realizada por Karl Marx (1818-1883), foi atingida a suprema possibilidade da Filosofia. A Filosofia entrou no seu estágio terminal.” (Heidegger, 1987c, p. 72). 
Na medida em que a nova ciência fundamental é a cibernética teoria do controle de planificação e de organização do trabalho humano, o domínio sobre o saber passa a ser exercido pelas operações e modelos do pensamento representacional calculador.

Não é necessário ser profeta para reconhecer que as modernas ciências que estão se instalando serão, em breve, determinadas e dirigidas pela nova ciência básica que se chama cibernética. Esta ciência corresponde à determinação do homem como ser ligado à praxis na sociedade. Pois ela é a teoria que permite o controle de todo planejamento possível e de toda organização do trabalho humano. A cibernética transforma a linguagem num meio de troca de mensagens. As artes tornam-se instrumentos controlados e controladores da informação. (Heidegger, 1987c, p. 72)

Mas algo incomoda na era cibernética: a falta de um questionamento da essência da técnica moderna, que se impõe cada vez mais através de suas inegáveis eficácia e utilidade. Uma questão se insinua aqui: será que em nossa época foram realizadas todas as possibilidades em que o pensamento da Filosofia apostou? Em que sentido podemos considerar que estamos numa época pós-humanista? $\mathrm{Na}$ tentativa de compreender melhor o alcance de tais questões, vamos retomar a crítica heideggeriana ao humanismo, que teria perdido sua capacidade de realmente educar-amansar o homem, além de desvirtuar o verdadeiro caráter de sua essência. Será que a questão sobre o cuidado e formação do ser humano não se deixa mais formular de modo pertinente no campo das meras teorias da domesticação e educação?

\section{Crise do humanismo na era da técnica e a questão da formação humana}

Em uma palestra feita em 1999 e que se transformou em um pequeno livro intitulado Regras para o parque humano ${ }^{4}$, o pensador Peter Sloterdijk

${ }^{4}$ Cf. Sloterdijk, Peter. Regras para o parque humano: uma resposta à Carta sobre o humanismo de Heidegger. Trad. José Oscar de Almeida Marques. SP: Estação Liberdade, 2000 .

Filosofia e Educação - ISSN 1984-9605

Volume 6, Número 3 - Outubro de 2014 
considerou que a humanitas, desde os tempos de Cícero, faz parte das consequências da alfabetização. Daí a natureza e a função do humanismo: propiciar e cultivar a amizade por meio da escrita. Saber ler e escrever sempre significou algo como participar de uma confraria de amigos forjada na leitura de alguns clássicos. Assim, os humanizados nesse contexto de erudição referia-se a uma seita de alfabetizados com projetos universalistas. (Cf. Sloterdijk, 2000)

O fato é que um dos aspectos fundamentais desse humanismo é sua imposição dos clássicos à juventude, que deveria tomar posse do imenso e rico patrimônio cultural da humanidade, identificando-se como parte de uma totalidade (cf. Sloterdijk, 2000). Entretanto, hoje, no crepúsculo da Era atômica, o humanismo nacional-burguês (iluminista) chegou ao fim, uma vez que a arte de ler e escrever já não basta para criar uma comunidade de amigos entre os habitantes de uma sociedade de massas, domesticada e alienada na produção e no consumo e na qual há apenas sobreviventes indiferentes e impotentes até mesmo para sofrer.

Com o advento do rádio, da televisão e hoje com a internet, a coexistência humana nas sociedades atuais e a própria natureza das relações de poder são retomadas em novas bases, que Sloterdijk chama de póshumanistas. "É apenas marginalmente que os meios literários, epistolares e humanistas servem às grandes sociedades modernas para produção de suas sínteses políticas e culturais." (Sloterdijk, 2000, p. 14). Livros e cartas não têm mais papel predominante na elaboração da síntese sóciocultural. O humanismo moderno, que oferece os pressupostos, princípios, valores e finalidades do que se convencionou chamar de formação humana e construção da cidadania via educação, teria se esgotado como modelo de escola, formação e emancipação humana. Mas em que sentido vivemos em uma época pós-humanista? Para Sloterdijk, em 1946 Martin Heidegger escreveu uma carta intitulada Sobre o humanismo que inauguraria uma época que se pode considerar pós-humanista. Nesse texto o filósofo interroga sobre as condições do humanismo europeu ao tentar responder

Filosofia e Educação - ISSN 1984-9605

Volume 6, Número 3-Outubro de 2014 
uma questão posta por Jean Beaufret - Como conferir novamente um sentido à palavra humanismo? (1983a). Heidegger, certamente marcado pelas tragédias e pelos horrores da Segunda Guerra Mundial, pergunta se “[...] já não é suficientemente óbvio o desastre que todos os títulos desse tipo anunciam?" (Heidegger, 1983 apud Sloterdijk, 2000, p. 22).

Sem complacência com as teorias ditas humanistas, Heidegger mostra que o termo humanismo não tem que ser apenas ressignificado, ele tem que ser abandonado. Não há mais lugar para a exaltação do ser humano enquanto membro de uma comunidade de amigos forjada na leitura das grandes obras de nossa cultura. A história humana está repleta de catástrofes que parecem mostrar que o problema é o próprio ser humano e seus sistemas de auto-elevação e auto-explicação que recebem o nome genérico de humanismo.

Quando Heidegger, na carta Sobre o humanismo, propõe o abandono do termo humanismo, o filósofo coloca em questão as três principais respostas à crise europeia de 1945 que são: o cristianismo, o marxismo e o existencialismo cristão ou ateu. Todos variedades de humanismo que procuram evitar " a radicalidade última da questão sobre a essência do ser humano." (Cf. Heidegger, 1987b). Toda espécie de humanismo padece de uma crônica incapacidade de colocar de forma adequada a questão sobre a essência do ser humano, que deve ser compreendida nos marcos da analítica existencial de Ser e Tempo. Heidegger rejeita o humanismo e toda filosofia que tome o homem como "medida de todas as coisas", até mesmo do próprio Ser. O homem é apenas “o pastor do ser” (cf. Heidegger, 1950; 1987b).

O fato é que os humanismos em suas diferentes formas (cristianismo, marxismo, existencialismo) obstruíram, com suas interpretações apressadas e equivocadas da essência do ser humano, uma genuína discussão sobre a essência humana tal como foi colocada em Ser e Tempo (1927). Por mais que as espécies de humanismos distingam-se entre 
si, em suas metas e fundamentos, e conforme a maneira e os meios de cada realização, todas elas coincidem nisto:

[...] que a humanitas do homo humanus é determinada a partir do ponto de vista de uma interpretação fixa da natureza, da história, do mundo. [...] $\mathrm{Na}$ determinação da humanidade do homem, o humanismo não apenas deixa de questionar a relação do ser com ser humano. Mas o humanismo tolhe mesmo esta questão, pelo fato de, por causa de sua origem da Metafísica, não conhecê-la nem compreendê-la. (Heidegger, 1987b, p. 19)

Mas como Heidegger pretende corrigir ou oferecer uma alternativa aos humanismos? Devemos em primeiro lugar renunciar a uma errônea subestimação do homem. "A questão sobre a essência do ser humano não entra no rumo certo até que nos afastemos da mais velha, mais obstinada e mais perniciosa das práticas da metafísica europeia - definir o ser humano como animal rationale." (Heidegger, 1987b, Apud Sloterdijk, 2000, p. 24-25). Na compreensão metafísica de homem como animal racional, este continua a ser entendido como animal com algumas propriedades entre as quais a capacidade de pensar. Ora, analítica existencial de Ser e Tempo rejeita a ideia de que a animalidade e a racionalidade sejam constitutivas da essência humana. Ser e Tempo revela que a essência do homem reside em sua ec-sistência, que não se identifica com o conceito tradicional de existentia, enquanto realidade efetiva que se diferencia da essentia enquanto possibilidade. A essência humana, portanto, não pode ser compreendida na dimensão zoológica ou biológica, ainda que acrescida da racionalidade. Não há nenhuma ligação ontológica entre o animal e o homem, não há uma diferença de gênero ou espécie, mas uma diferença ontológica, de modo de ser e estar no mundo. O Homem não é e não deve ser concebido apenas como um animal dotado de razão. $O$ homem enquanto existente instaura uma radical distância em relação aos animais e demais 
entes. Enquanto existente, ele se faz como um constante arrancamento para fora de si, um ser simplesmente aí jogado sob condições que não escolheu e a partir das quais terá que fazer escolhas.

O que a analítica existencial de Ser e Tempo nos mostra é que o homem é um ser no mundo, que mora, habita o mundo e o constitui enquanto complexo de relações, remissões, significados que surgem na medida em que ele é obrigado a preocupar-se com os outros e ocupar-se com as coisas. O homem mantém uma relação de familiaridade, comprometimento com o mundo no qual habita. A dignidade humana, sua singularidade, em relação às demais coisas, não reside, pois, no fato de ele possuir uma sensibilidade que o faz criar uma obra de arte, ou uma racionalidade que lhe dá o controle e o domínio sobre a totalidade das coisas. A dignidade humana estaria no fato do homem ser o escolhido pelo Ser, o que faz da existência humana uma clareira na qual o ser dos entes pode desvelar-se no dizer e no pensar do homem, ainda que originariamente ele esteja afundado na impessoalidade e tagarelice que nada diz.

Devemos considerar que o pensamento e a linguagem são dádivas do ser ao homem, daí o pensar e o falar deveriam ser atos de agradecimento ao Ser por fazer de nós seus guardiões. A linguagem é antes "a casa do ser; ao morar nela o homem existe, à medida que compartilha a verdade do ser, guardando-a. O que importa na definição da humanidade do ser humano enquanto existência, é que o essencial não é o ser humano, mas o ser..." (Heidegger, 1987b, p. 24).

Muitos alertam que a critica heideggeriana ao humanismo e seus princípios iluministas, cristãos, existencialistas, conduziria a um antihumanismo. O filósofo procura evitar essa queda no inumano, sem aceitar, contudo, que o humanismo tenha explicado suficientemente a essência do homem. Sloterdijk observa que Heidegger preserva uma das funções mais importantes do humanismo clássico: a amizade do ser humano pela palavra do outro. O homem como pastor do ser tem a missão de guardar o ser, buscar uma correspondência a ele naquilo que sente, pensa, diz e faz. Com

Filosofia e Educação - ISSN 1984-9605

Volume 6, Número 3-Outubro de 2014 
Heidegger, o homem ganha a essencial pobreza e simplicidade do pastor, mas sua dignidade residiria no fato de ter sido chamado pelo próprio ser para guardar a sua verdade. "O homem é, em sua essência ontológicohistorial, o ente cujo ser como ec-sistência consiste no fato de morar na vizinhança do ser. O homem é o vizinho do ser." (Heidegger, 1987b, p. 29). Para Sloterdijk, ao definir o ser humano como pastor e vizinho do ser, e ao chamar a linguagem de casa do ser, Heidegger vincula o homem ao ser em uma correspondência que lhe impõe uma restrição radical - o pastor vive na proximidade ou nas cercanias da casa, mas ao mesmo tempo ele goza da dignidade de ter sido o escolhido para guardar o ser naquilo que pensa e diz. (Sloterdijk, 2000, p. 28)

Heidegger, portanto, não é existencialista nem humanista, pois acredita que um verdadeiro acesso ao ser do homem e da própria realidade exige a destruição desses preconceitos metafísicos acerca do Ser e do próprio homem. Se o ente humano é definido em seu ser pela compreensão do Ser, isso significa que a relação que se estabelece entre o homem e o Ser não só compreende o conhecimento ou a razão humana, senão também o homem todo em seu ser-no-mundo.

Mas o que ainda forma o homem, se o humanismo fracassou como escola da domesticação humana, enquanto forma de controlar as tendências desinibidoras? $\mathrm{O}$ que educa o homem, se em todas as experiências prévias com a educação do gênero humano permaneceu obscuro o que ou o quem educa os próprios educadores? O fato é que o ser humano é uma força criadora e domesticadora de coisas e homens. Nietzsche percebeu isso.

Em todos os lugares, vejo portões mais baixos... Ando por entre esse povo mantendo os olhos abertos. Eles se tornaram menores e ficam cada vez menores - nisso consiste sua concepção de felicidade... Alguns deles querem, quanto a maioria porém, outros querem por eles. São redondos, corretos e bons uns com os outros... Abraçar 
modestamente uma pequena felicidade - a isso chamam resignação... Querem no fundo ingenuamente uma coisa acima de tudo - que ninguém lhes faça mal... Virtude é para eles aquilo que torna modesto e domesticado - fazem do lobo um cão e dos próprios homens os melhores animais domésticos para os homens. (Nietzsche, 1986, p. $82)$.

Os homens da atualidade são acima de tudo bem sucedidos criadores que conseguiram fazer do homem selvagem o último homem. O que seria a educação senão um sistema que insiste em banir as exceções a favor do medíocre. O que são escolas, famílias, igrejas senão lugares onde se amansa a besta humana e se ensina, não a viver a vida, mas a sobreviver uma vida bestializada e impotente. A tese do ser humano como criador, domesticador de seres humanos faz explodir o horizonte humanista (cf. Sloterdijk, 2000). O humanista assume o homem como dado e aplica-lhe então seus métodos de domesticação, treinamento e formação. Nietzsche percebe, contudo, que por trás da domesticação escolar dos homens, descortina-se um horizonte sombrio. Lutas intermináveis surgirão sobre o direcionamento da criação de seres humanos. $\mathrm{O}$ fato de o homem ter ficado menor, tornando-se uma besta do trabalho dócil, é o resultado de uma política de criação indiscutível. Os homens conseguiram com ajuda de uma hábil combinação de genética e ética criar a si mesmos para serem menores. "Eles próprios se submeteram a domesticação e puseram em prática sobre si mesmos uma seleção direcionada para produzir uma sociabilidade a maneira de animais domésticos". (Sloterdijk, 2000, p. 40).

Em sua suspeita contra a cultura humanista, Nietzsche aponta aqueles que detêm o monopólio da criação-domesticação dos homens: padres, professores, autoridades apresentam-se como amigos do homem e ensejam disputas entre correntes de criadores e diferentes projetos de criação. Esse será o conflito do futuro, a luta entre os que criam o ser 
humano para ser pequeno e os criam para ser grande, pensando e sentindo além de bem e mal e inocentando a vida mesmo na dor e no sofrimento.

O que a perspicácia de Nietzsche denuncia é que a domesticação do ser humano é o ideal inconfessado de toda espécie de humanismo que acredita que pode melhorar o homem via educação. Entretanto, seria ingênuo e simplista pensar que esse processo de domesticação do ser humano se deu através da leitura de alguns clássicos. A leitura teve um imenso poder na formação humana, mas é a seleção (hoje baseada na meritocracia) que opera por trás da proposta de formação do humanismo. Nesse sentido, Peter Sloterdijk fala da necessidade de se formular um código das antropo-técnicas que alteraria retroativamente o significado do humanismo - a humanitas não inclui só a amizade do ser humano pelo ser humano via textos, cartas, ela implica também que o "homem representa o mais alto poder para o homem..." (Nietzsche, 1986, p. 86).

\section{Para não concluir}

Não há como negar que, apesar da aparente abundância de meios e produtos técnicos disponíveis para nosso uso e consumo, vivemos um tempo de indigência e penúria, que não pensa, mas apenas planifica e calcula. Entretanto, é no âmbito mesmo dessa indigência e penúria que surge a possibilidade do advento de uma nova forma de pensar e dizer mais originárias e que poderão nos libertar desse desterramento e sensação de estranhamento diante de um mundo cada vez mais uniformizado pelo cálculo.

Permanece incerto, por exemplo, se a civilização mundial será em breve subitamente destruída ou se cristalizará numa longa duração que não resida em algo permanente, mas que se instale, muito ao contrário, na mudança contínua em que o novo é substituído pelo mais novo - o reino da Ersatz (Substituição). Não é por acaso, pois, que hoje assistimos a um colossal e gigantesco processo de planificação e burocratização, de 
uniformização de estilos de vida, de instrumentalização da linguagem e de esfacelamento do sagrado.

Desde o início do Século XX, observa Heidegger, a existência começou a desligar para um mundo sem profundidade. Todas as coisas escorregam para um mesmo nível, para uma superfície. A dimensão dominante tornou-se a da extensão e do número. Doravante, capacidade quer dizer o exercício de uma rotina, suscetível de ser aprendida por todos, conforme certo esforço. (Heidegger, 1987a, p. 71-72). Decisiva é a transformação do Espírito em Inteligência instrumental: a Inteligência instrumental é uma mera habilidade ou perícia no exame, no cálculo e na avaliação das coisas. A Ciência emerge dessa degradação do mundo do Espírito em Inteligência instrumental, fragmentando-se numa multiplicidade de disciplinas que estão a serviço das profissões. (cf. Heidegger, 1987a). Para Heidegger, entretanto, nós não devemos nos deixar levar por nenhum ativismo ou qualquer espécie de revolta diante da técnica, sob pena de cair na armadilha do pensamento calculador. Nenhuma ação jamais conseguirá provocar qualquer mudança na essência da técnica, e muito menos na essência do Ser e do homem. Não temos nada a fazer para evitar ou amenizar os efeitos devastadores do domínio planetário da técnica, só nos resta esperar. Uma espera que não significa submissão ou resignação. Nesse sentido, nenhuma instituição ou doutrina de caráter ético-político poderá promover a superação da situação presente.

O fato é que, apesar da emergência de novos paradigmas no campo das ciências, de novos agenciamentos dos saberes que impõe uma visão holística, sistêmica, inter-transdisciplinar, em relação a formação humana prevalece ainda a valorização extrema, quase que obsessiva, da eficácia e eficiência no funcionamento dos dispositivos tecnológicos, entre os quais se encontraria a escola e a universidade. A busca por mais eficiência e produtividade, exige a prática sistemática da competição com os outros e consigo mesmo. Nesse sentido, a eficácia incondicionada e a competição tornam-se critérios últimos de hierarquização, ordenação e

Filosofia e Educação - ISSN 1984-9605

Volume 6, Número 3 - Outubro de 2014 
avaliação dos diversos dispositivos tecnológicos a serviço da formação humana.

As universidades atuais assumem uma missão tecnocrática contentando-se em preparar mão de obra para o mercado de trabalho, entretanto isso não é responsabilidade de nenhum sujeito ou instituição determinada, não é fruto de uma decisão arbitrária de algum tecnocrata. $\mathrm{O}$ que seria necessário fazer, dentro das limitações impostas por nossa condição de "funcionários da técnica", para que a escola e a universidade voltem a constituírem-se em genuínos e autênticos poderes espirituais? Como fazer da universidade a mais alta escola do povo apta a formar homens a altura das tarefas e desafios de nosso tempo? A questão da fragmentação da universidade em departamentos, por exemplo, reflexo da inteligência cega (Morin) e do predomínio do discurso da competência, sempre era questionada por Heidegger quando o pensador se interrogava sobre a missão da universidade. Em Que é Metafisica? (Was ist Metaphysik), o filósofo considera que:

[...] os domínios das ciências estão muito distantes entre si. O modo de tratar seus objetos é radicalmente diferente. Essa dispersa multiplicidade de disciplinas se mantém, contudo, unida graças tão somente a organização técnica das universidades e faculdades, e conserva uma significação pela finalidade prática das especialidades. Ao contrário, o enraizamento das ciências em seu fundamento essencial se perdeu por completo (Heidegger, 1979, p. 2).

Infelizmente, a educação, hoje, refém do mercado, está impossibilitada de buscar um equilíbrio no uso do cálculo e da planificação em seus modelos de gestão, em suas pesquisas e nos conteúdos programáticos das diversas disciplinas. O pensamento calculador erige-se como a única maneira de pensar válida, como consequência, o conhecimento científico, com seu método experimental/matemático, torna- 
se o único digno de ser ensinado, em detrimento de outras formas de narrativas e experiências (arte, religião, filosofia, etc.) fundamentais para o processo de humanização do homem. Diante desse cenário aparentemente estéril e inóspito do mundo uniforme do cálculo, Heidegger nos aconselha a serenidade (Gelassenheit) - uma atitude que nos faz inserir e utilizar de forma conveniente os dispositivos tecnológicos, evitando que sejamos triturados e devastados por eles.

A questão é: estaríamos nós, filhos de uma época uniformizada pelo cálculo, aptos a resgatar uma relação mais originária com os outros e com as coisas? Vale a pena vender tão caro nossa liberdade por todo esse aparato de segurança e um certo conforto material, que só nos tornam mais indolentes e alienados em relação às nossas mais autênticas necessidades e capacidades? Em último caso, cabe a nós decidir se da noite desse tempo de penúria e indigência surgirá uma nova forma de ser e estar no mundo. Enquanto isso, errando por uma terra devastada e uniformizada pelo cálculo, o homem continua a procura de si mesmo.

\section{Referências}

\section{Obras citadas}

HEIDEGER, Martin. "Que é Metafísica?” In: Conferências e Escritos Filosóficos. SP: Abril Cultural, 1979. - A auto-afirmação da Universidade alemã. Trad. Fausto Castilho. Curitiba: Sec. de Estado da Cultura, 1997. .Caminos del Bosque. Madrid, 1997.

. Da experiência do Pensar. Trad. Maria do Carmo T. Miranda. Porto Alegre: Globo, 1969. . Essais et Conférences. Trad. A. Preau. Paris: Gallimard, 1958.

. Fim da Filosofia e a tarefa do pensamento. In: Conferências e Escritos Filosóficos. Trad. Ernildo Stein. São Paulo: Abril cultural, 1987c. - Introdução à Metafísica. Trad. Emanuel Carneiro Leão. Rio de Janeiro: Tempo Brasileiro, 1987a.

Filosofia e Educação - ISSN 1984-9605

Volume 6, Número 3 - Outubro de 2014 
. La question de la tecnique. In: Essais et Conferences. Paris: Gallimard, 1958a. . Ser e Tempo. Trad. Marcia S. Cavalcant. Petrópolis: Ed. Vozes, 1988.

.Sobre o Humanismo. In: Conferências e Escritos Filosóficos. Trad. Ernildo

Stein. São Paulo: Abril cultural, 1987b.

.Ultrapassamento da Metafísica. In: Essais et Conferences. Paris: Gallimard, 1958b.

LOPARIC, Zeljko. Heidegger e a pergunta pela Técnica. Caderno de História e Filosofia da Ciência 6 (jul-dez. 1996): 107-138.

NIETZSCHE, Wilhelm Friedrich. Assim falava Zaratustra. Trad. Mário da Silva. Rio de Janeiro: Civilização Brasileira, 1986.

SLOTERDIJK, Peter. Regras para o parque bumano: uma resposta à carta de Heidegger sobre o humanismo. Trad. José Oscar de Almeida Marques. São Paulo: Estação Liberdade, 2000.

\section{Obras Consultadas}

AGAMBEN, Giorgio. Homo Sacer: O Poder Soberano e a Vida Nua. Trad. António Guerreiro. Lisboa: Presença, 1998. . Estado de exceção. Trad. Iraci D. Poleti. São Paulo: Boitempo, 2004.

BADIOU, Alain. A situação da Filosofia no mundo contemporâneo. In: Para uma nova teoria do sujeito: conferências brasileiras. (Relume-Dumará), 1994.

DREYFUS Hubert. De la tekhne a la technik. In: Cahier de L'Herne - Heidegger. Paris: Ed. L’Herne, 1983.

FARIA, Vitor. Heidegger e o nazismo. Rio de Janeiro: Paz e Terra, 1985.

FOUCAULT, Michel. Nascimento da biopolítica. Trad. Eduardo Brandão. São Paulo: Martins Fontes, 2008.

GIACOIA, Oswaldo. Corpos em fabricação. In: Naturez̧a Humana, 5 (1), pp. 175202, jan.-jun. 2003.

HABERMAS, J. O Discurso Filosófico da modernidade. Trad. Ana Maria Bernardo et ali. Lisboa: Pub. Dom Quixote, 1990, p. 131-156.

JÜNGER, Ernst, Der Arbeiter. In: Werke. Band 6. Essays II, Ernst Klett Verlag, Stuttgart, 1960-1965. 
. Le Travailleur. Trad. e apresentação Julien Hervier. Paris: Christian Bourgois Éditeur, 1989.

LEVY, Pierre. As tecnologias da Inteligência. Rio de Janeiro: Ed. 34, 1993.

LOPARIC, Zeljko. A fabricação dos humanos. In: Manuscrito - Revista de Filosofia, Campinas, v. 28, nº. 2, pp. 391-415, jul. - dez. 2005.

LYOTARD, J-F. Pós-Moderno. São Paulo: José Olympio, 1979.

MORIN, Edgar. Educação e complexidade. São Paulo: Cortez, 2005.

- Educar na era planetária. Trad. Sandra Trabucco. São Paulo: Cortez, 2002, cap. I.

NIETZSCHE, Friedrich. Considerações Extemporâneas. In: "Obras incompletas".

Trad. Rubens R. Torres Filho. São Paulo: Abril Cultural, 1978.

Schopenhauer como Educador. In: “Obras incompletas". Trad. Rubens R.

Torres Filho. São Paulo: Abril Cultural, 1978, p. 327-344.

PELBART, Peter pal. Biopolítica. In: Sala Preta. USP-ECA, V. 7, n. 1, 2007.

Disponível em: http://www.eca.usp.br/salapreta/PDF07/SP07_08.pdf Acessado em 15/09/2012.

PESSIS-PASTERNAK, Guitta. Do Caos à Inteligência artificial. Trad. Luiz Paulo Rounet. São Paulo: Ed. Unesp, 1993.

PLATÃO. Diálogos. Seleção de textos de José Américo Motta Pessanha; Trad. e notas José Cavalcante de Souza, Jorge Paleikat e João Cruz Costa. São Paulo: Abril Cultural, 1983.

PRIGOGINE. A Nova Aliança. Brasília: Ed. UnB, 1984. 